\title{
A bio-economic model for cost analysis of alternative management strategies in beef finishing systems
}

\author{
C. Kamilaris ${ }^{\mathrm{a}, \mathrm{c}, *}$, R.J. Dewhurst ${ }^{\mathrm{a}}$, B. Vosough Ahmadi ${ }^{\mathrm{a}}$, P. Crosson ${ }^{\mathrm{b}}$, P. Alexander ${ }^{\mathrm{c}, \mathrm{d}}$ \\ ${ }^{a}$ Scotland's Rural College (SRUC), Kings Buildings, West Mains Road, Edinburgh, EH9 3JG, UK \\ ${ }^{\mathrm{b}}$ Animal and Grassland Research \& Innovation Centre, Teagasc, Grange, Dunsany, Co. Meath, Ireland \\ ${ }^{\mathrm{c}}$ School of Geosciences, University of Edinburgh, Drummond Street, Edinburgh, EH8 9XP, UK \\ d Global Academy of Agriculture and Food Security, The Royal (Dick) School of Veterinary Studies and The Roslin Institute, Easter Bush Campus, Midlothian, EH25 9RG, \\ $U K$
}

\section{A R T I C L E I N F O}

\section{Keywords:}

Beef production systems

Bio-economic modelling

Finishing stage

Economic viability

\begin{abstract}
A B S T R A C T
Global population growth together with rising incomes is increasing the demand for meat-based products. This increases the need to optimize livestock production structures, whilst ensuring viable returns for the farmers. On a global scale, beef producers need tools to assist them to produce more high-quality products whilst maintaining economic efficiency. The Grange Scottish Beef Model (GSBM) was customized to simulate beef finishing enterprises using data from Scottish beef finishing studies, as well as agricultural input and output price datasets. Here we describe the model and its use to determine the cost-effectiveness of alternative current management practices (e.g. forage- and cereal-based finishing) and slaughter ages (i.e. short, medium or long finishing duration). To better understand drivers of profitability in beef finishing systems, several scenarios comparing finishing duration, gender, genetic selection of stock for growth rate or feed efficiency, as well as financial support were tested. There are opportunities for profitable and sustainable beef production in Scotland, for both cereal and forage based systems, particularly when aiming for a younger age profile at slaughtering. By careful choice of finishing systems matched to animal potential, as well as future selection of high performing and feed efficient cattle, beef finishers will be able to enhance performance and increase financial returns.
\end{abstract}

\section{Introduction}

Global consumer demand for food is expected to rise due to population growth and increased per capita incomes, with developing countries expected to experience a marked increase in consumption of animal products (Alexander et al., 2015; Godfray et al., 2010; Tilman and Clark, 2014). During recent decades, there have been large changes in the structure of the developing world's diet, with a move away from a starch dominated diet to one with more energy from animal products (Popkin, 2006). A shift to a more western diet, with higher levels of protein intake, will lead to an expected $21 \%$ increase in beef consumed in developing countries over the next decade, with $45 \%$ of additional beef demand attributed to Asian markets (Agriculture and Horticulture Development Board, 2017; OECD/FAO, 2017). This "westernization" of Asian diets results will increase demand for high-value temperate zone products, transforming food supply systems and providing export opportunities (OECD/FAO, 2017; Pingali, 2007).

Every region's agriculture activities are related to land type; the pasture-based agricultural landscape of Scotland indicates that the ruminant livestock sector, and principally cattle production, is the main agricultural activity (ERSA, 2016; Vosough Ahmadi et al., 2015). Scotland's economy is extremely reliant on ruminant livestock farming, while in terms of dependency on cattle production across European Union (EU) states, the region is second only to Ireland (Ashworth, 2009). Nevertheless, producers tend to report low or negative margins and rely greatly on Common Agricultural Policy (CAP) support payments to sustain their farming activities (Scottish Government, 2014). This increasing reliance on subsidies raises concerns over the sector's financial performance and stability (AHDB, 2016). To capitalize on future opportunities, the challenge for Scotland's beef industry will be to make optimum use of resources and unlock the best combination of management practices to improve production efficiency and profitability. Scottish forage-based beef production systems might be sustainable in environmental terms, but economic sustainability is yet to be achieved for most farms, partly due to a volatile business environment and uncertain price conditions (Scottish Government, 2014).

\footnotetext{
* Corresponding author at: Scotland's Rural College (SRUC), Kings Buildings, West Mains Road, Edinburgh, EH9 3JG, UK.

E-mail address: harry.kamilaris@sruc.ac.uk (C. Kamilaris).
} 
There is a need to investigate adaptations that counter the effects of uncertainty by helping farmers building strategies to capitalize on the region's unique assets (AHDB, 2016).

Simulation models enable researchers to investigate and reveal possible impacts of changes in agricultural production technologies. This often leads to designing tools that can complement, and even substitute for, conventional, 'on-the-ground' experimental methods (Antle et al., 2017; Bywater and Cacho, 1994). Beef production systems can be investigated with mathematical models to explore various sets of farm constraints, policy parameters and management alternatives (Nielsen et al., 2004; Rotz et al., 2005; Tess and Kolstad, 2000; van Calker et al., 2004; Veysset et al., 2005). A number of authors have established simulation models to study beef cattle growth and carcass composition (Hoch and Agabriel, 2004; Kilpatrick and Steen, 1999), beef production systems (Crosson et al., 2006a), ration formulation (Oltjen and Ahmadi, 2013), slaughtering policies (Nielsen et al., 2002), feed intake and animal performance (Rotz et al., 2005), feeding strategies (Bonesmo and Randby, 2010), decisions during the fattening process (Makulska and Kristensen, 1999), systems' technical efficiency (Ruiz et al., 2000) and various innovation options (Ash et al., 2015).

Although, these studies have covered various beef production issues, there is a need for livestock simulation modelling approaches based on region-specific robust datasets that will be effectively preparameterized for conditions common to the system examined (Antle et al., 2017). Here, a static simulation model utilized Scottish beef farm systems as a case study for a methodology that could be used to explore cost effectiveness of beef finishing in other regions. The aim of this study was to assemble information to support a decision-making process contributing to the development of cutting-edge farm-management systems that address low profitability (Jones et al., 2017). The paper describes the structure of the Grange Scottish Beef Model (GSBM). The model is then applied, to investigate scenarios that study the effects of variation in market conditions, policy environment and management practices on enterprise profitability.

\section{Model description}

The GSBM shares a common structure with farm systems models developed by Teagasc (The Agriculture and Food Development Authority in the Republic of Ireland) (Ashfield et al., 2014b, 2013; Bohan et al., 2016; Crosson et al., 2015; Crosson et al., 2006a; Finneran et al., 2012). Thus, the approach was to develop a biophysical depiction of the farm system within a single year, adopting a static and deterministic framework with provision for an economic analysis of annual performance. The animal nutritional data and equations used in another model developed by Teagasc were considered appropriate due to the similarity of production systems, climate and breeds between Scotland and Ireland (Ashfield et al., 2013; Heaton et al., 2008). Furthermore, European market specifications are shared between the two regions (Quality Meat Scotland, 2017). The GSBM diverged from previous Teagasc models to provide a dedicated depiction of the Scottish beef finishing sector, including a range of production systems reflecting the variety of options available to beef farmers.

\subsection{Origin of experimental data}

Data were obtained from experiments in Scotland to define the main coefficients and production functions (Bell et al., 2016; Hyslop et al., 2016). Production systems modelled were based on the "Lifetime growth pattern and beef eating quality" ("Growth Path") project, previously reported by AHDB Beef \& Lamb (Hyslop et al., 2016). This three year study was selected because Limousins were the most used beef sire in Scotland and the UK between 1997-2017 (Quality Meat Scotland, 2017). A total of 72 animals entered the study at 12 months of age (yearlings) and were taken through divergent finishing strategies; offered either a mixture of concentrates with forage based finishing diets or grazing on diverse quality grasslands. Steers and heifers, representative of the Limousin crossbred beef cattle genotype, experienced three different treatments that led to three distinct "growthpaths" (Hyslop et al., 2016). Further details of the Growth path study are included in the Supplementary Material.

The model simulates two genders of one important genetic type (Limousin crossbreds) under three management regimes. Modelling of individual systems was based on growth patterns recorded in the study, which represent production systems typical of commercial practice for UK and Scottish farms (Hyslop et al., 2016). Six production options were modelled, which represent the short, medium and long finishing treatments along with two genders (steers and heifers), reproducing the continuous experimental design of the "Growth Path" trial.

Instead of employing generic growth curves, animal growth curves were adopted from the "Growth Path" experiment dataset (Hyslop et al., 2016). Fig. 1 shows the difference between these curves and those produced using INRA equations for late maturing steers and heifers (Sauvant et al., 2018). Whilst the standard INRA curves corresponded closely for medium-duration finishing systems, they under-predicted for short-duration and over-predicted form long-duration finishing systems. In beef finishing systems, when animals are sufficiently fed after a period of reduced energy via restricted nutrition, the physiological process of compensatory growth is observed, which signifies a period of enhanced growth compared with those not submitted to feed restriction (Hornick et al., 2000; Sainz et al., 1995). Previous studies have highlighted the role of compensatory growth when estimating beef cattle performance (Hoch and Agabriel, 2004; Keele et al., 1992; Oltjen et al., 1986). In addition, compensatory growth could influence a farm' financial performance (Ashfield et al., 2014b), as it can be employed as a strategy to reduce feeding costs (Lopes et al., 2018), and it was found to have an effect on meat's sensory characteristics and quality (Keady et al., 2017). The variability in experimentally-derived growth curves was a result of actual feed availability, and this was particularly obvious for the long-duration finishing systems which incorporated two grazing periods.

\subsection{Model components}

To investigate production related scenarios, an existing model, the Grange Dairy Beef Systems Model (GDBSM), was used as a base, reparameterized and adjusted to fit Scottish conditions (Ashfield et al., 2013). The GDBSM was developed to evaluate grassland based dairy calf to beef production systems in Ireland (Ashfield et al., 2013, $2014 c$,a). Similar to the structure of GDBSM, this model also consists of four sub models i.e. the farm system, animal nutrition, feed supply and financial performance. Each component of the model will be briefly discussed, along with alterations and adjustments made to develop a regionalized model for Scotland. A representation of the approach adopted during the development of the GSBM is demonstrated in Fig. 2.

\subsubsection{Farm system sub model}

The farm system sub model simulates the beef finishing system and calculates on a monthly basis the animal numbers, individual liveweights, housing requirements and slurry production during the indoor period. The finishing systems of the farm system sub model were redesigned to replicate animal treatments during the "Growth path" study. Simulation initiates when animals enter the farm on 1st May, which is typical for spring-born yearlings in Scotland (Hyslop et al., 2016). The exception to this is cattle on short duration systems, which entered the farm on 1 st March. Animals were assumed to be purchased at the prevailing yearling store price. Additional cattle purchases can occur at any time during the finishing stage. The default mortality rate was set to $2 \%$, equally distributed over the year (SAC Consulting, 2017).

Live-weights were simulated based on initial variability measured during the "Growth Path" experiment and was calculated at the start of 

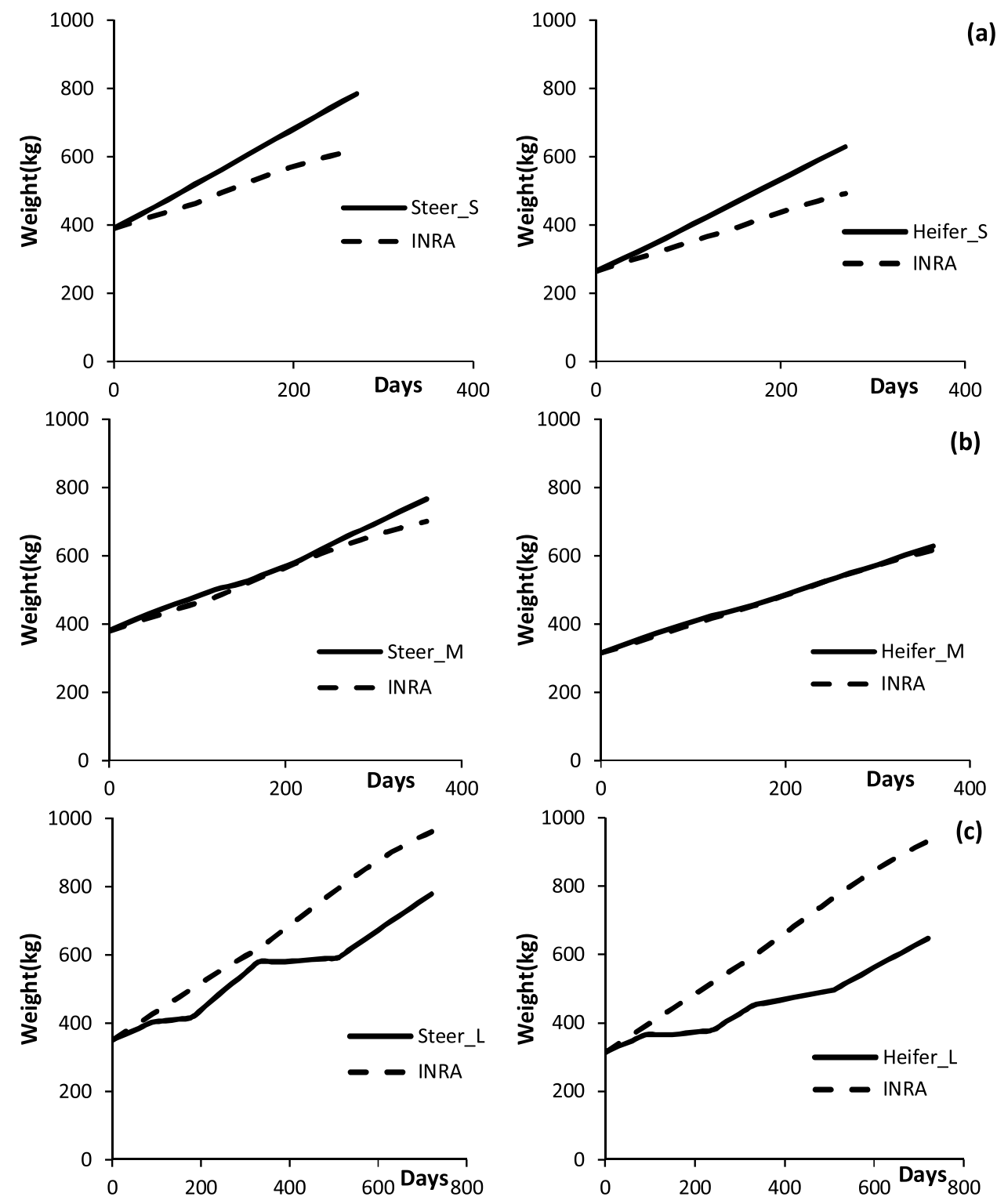

Fig. 1. Comparison of growth curves used in the GSBM with generic curves taken from the INRA model (Sauvant et al., 2018) for three different production options (finishing durations: short, medium, long) along with two genders (steers and heifers). (a): Steers and heifers on short duration system (i.e. Steer_S and Heifer_S). (b): Steers and heifers on medium duration system (i.e. Steer_M and Heifer_M). (c): Steers and heifers on long duration system (i.e. Steer_L and Heifer_L).

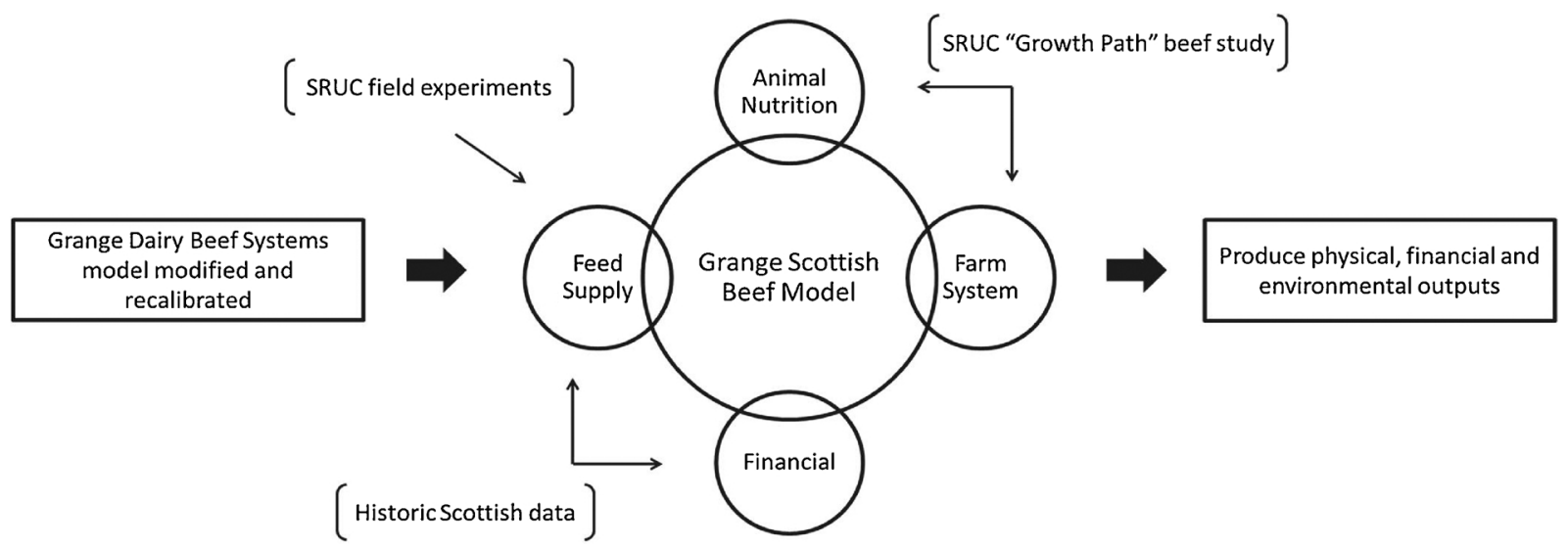

Fig. 2. Process of developing the Grange Scottish Beef Model. The development involved assembling data-sets from diverse sources, and employing them to inform the input values re-shaping the systems forming the GSBM sub models, in order to parameterise the model for Scottish conditions. 
each month and based on the previous month's starting live-weight and live-weight gain. Key default parameters like starting live-weight and monthly live-weight gains used data from the "Growth Path" experiment (Hyslop et al., 2016). The amount of slurry produced was based on number of animals, number of days spent indoors, as well as the amount of slurry produced per animal per day (SAC Consulting, 2017). All animals were accommodated in straw bedded systems and were supplied primarily with grass silage diets. Another assumption was that cattle were sold directly to abattoirs, and carcass data were obtained from the same experiment (Allen, 2014; Hyslop et al., 2016).

\subsubsection{Animal nutrition sub model}

The animal nutrition sub model controlled the energy demand and feed requirements of the modelled herd. It has been designed to calculate animal requirements and formulate diets using grazed grass, grass silage and concentrates to meet these demands (Ashfield et al., 2013). Nutritional specifications were described as animal energy requirements and were subject to a maximum intake capacity, which was described in Cattle Fill Units (CFU's). Energy requirements were specified in UFL's (Feed Unit for lactation) and UFV's (Feed Unit for maintenance and meet production) for growing and finishing animals respectively (Jarrige et al., 1986). The equations of Ashfield et al. (2013), based on liveweight and liveweight gain were adopted to calculate the net energy requirements and animal intake capacity for GSBM (Ashfield et al., 2013). In this version of the model protein requirements were not considered, as it was assumed that that fulfilment of energy requirements simultaneously satisfies protein requirements (Crosson et al., 2006b). The outputs of the model have been verified to ensure that the protein requirements of animals are satisfied (Crosson et al., 2006b). For a possible scenario where protein requirements have not been fulfilled, the user must specify to feed appropriate concentrates until requirements are met (Ashfield et al., 2013). Actual growth rates adopted from the "Growth path" study controlled the animal intake and were used as inputs to calculate net energy requirements. Moreover, feed grown in the farm was modelled as a constraint for forage intake, while brought-in concentrates offered compensate for the difference.

When simulating proportions of grass and forage fed, no silage was fed during the grazing period, and likewise no grazed grass was fed during the housing period. In instances where the forage quantity calculated for satisfying energy demands surpassed its intake capacity, the amount of forage originally considered was fed at the maximum level, with supplementary concentrates used to meet the total energy demand (Ashfield, 2014). But, the inclusion of concentrate lead to the reduction of forage intake and the extent of this replacement depends on the forage fill value and amount of concentrate fed. Thus, the "apparent fill" method was employed to calculate the change in forage dry matter per unit of additional concentrate fed (i.e. substitution rate) (Jarrige et al., 1986). The process selected was based on forage's apparent fill value (AFV), taking account of the ration energy density (RED) of the diet and the energy content of the forage (UFL or UFV). The model determine AFV based on tables previously published for a range of RED's and UFV's typical to temperate grasslands (Jarrige et al., 1986).

\subsubsection{Feed supply sub model}

The feed supply sub model regulates the forage system that calculated the grazed grass and grass silage production of the farm. Most of the land area of grassland based beef finishing systems in Scotland consists of permanent perennial ryegrass swards (Quality Meat Scotland, 2013). During peak growth periods, some of the perennial ryegrass swards are isolated for grass silage production. Supplementary concentrate feeds were purchased and used alongside the forage dietary components when required.
The grass grazing area was the total farm area minus the total area required for grass silage on a monthly basis. Grass growth (t DM/ha) was modelled based on a field experiment that took place at Crichton Royal Farm, Dumfries $\left(55^{\circ} 02^{\prime} \mathrm{N}, 3^{\circ} 35^{\prime} \mathrm{W}\right)$ in South-West Scotland, UK, on a long-term permanent grassland site (Bell et al., 2016). The data were used to generate an equation that predicts grass growth based on the nitrogen response (organic and inorganic) application rates $(\mathrm{kg} / \mathrm{ha}$ ). Expected yield and monthly distribution of grass growth throughout the year was calculated based on historic Scottish data from the Scotland's Rural College (SRUC) Dairy Research and Innovation Centre (Dumfries).

The utilization of grazed grass was fixed initially at $50 \%$ to reflect the level of performance of a set stocking grazing system for typical Scottish beef farms (Quality Meat Scotland, 2013). Two harvest regimes were modelled (one -harvest and two-harvests), using data published from the British Grassland Society to account for yield and quality parameters when cutting on different dates (Hopkins, 2000). It is typical on beef farms in Scotland for the first harvest to take place late in May or early June and the second approximately six weeks later, or else, depending on the weather and production systems selected, a single harvest might be taken in June (Farmers Guardian, 2017). Further details for modelled harvest dates, yields and silage quality are provided in Supplementary Material. Demand for grass silage, driven by the animal nutrition sub model, regulates the proportion of the area required for grass silage. When grass silage harvesting is complete, all of the farm area is available for grazing. Concentrate rations for the finishing animals were simulated as a typical Scottish barley-based concentrate with an energy content of 1.15 UFL or UFV $/ \mathrm{kg}$ DM (Quality Meat Scotland, 2017).

A key input was nitrogen $(\mathrm{N})$ application to the grazed area, since it determines the overall stocking rate. Stocking rates were defined as organic nitrogen output per hectare for cattle and, in accordance with the Nitrates Directive, the maximum amount of organic nitrogen output is limited to $170 \mathrm{~kg} \mathrm{~N} /$ ha for the UK (The Scottish Government, 2008). Specifications on nitrogen, phosphorus and potassium inputs originate from (Ashfield et al., 2013), as these figures were already embedded in the model, and they better characterize the stocking rate effect. The same principles apply to slurry production, its nutrient content and available nutrients. Slurry was allocated to the grass silage areas with $70 \%$ applied in spring and $30 \%$ over the summer, while its nutrient content was considered when calculating chemical fertilizer requirements. Whilst retaining the more complex Irish model, these estimates were consistent with the range of values suggested for Scotland in the Technical Note for fertilizer recommendations for grasslands (Sinclair et al., 2013).

\subsubsection{Financial sub model}

The key purpose of GSBM is to simulate the biological operation and economic performance of Scottish beef finishing enterprises. Recent Scottish pricing data were used as a baseline. Beef prices were calculated by gathering and analysing monthly data, publicly available from the Scottish Farmer, for the period of 2012-2017 (The Scottish Farmer, 2018). The beef price used in the model is a function of the conformation and fat class of the animal.

Seasonal and yearly fluctuation of beef prices were accounted by employing ModelRisk, a risk analysis add-in for Excel (Vose Software, 2018). Options include monthly average, with minimum and maximum monthly prices taken from the last five years as an input for both carcass and yearling store prices. Additionally, a stochastic approach was used, where ModelRisk fits normal and lognormal distributions to the carcass and store prices based on weekly data over the five year period of 2012-2017. Thus, the model generates random carcass prices and yearling store values for each run. This technique enhances the model's 


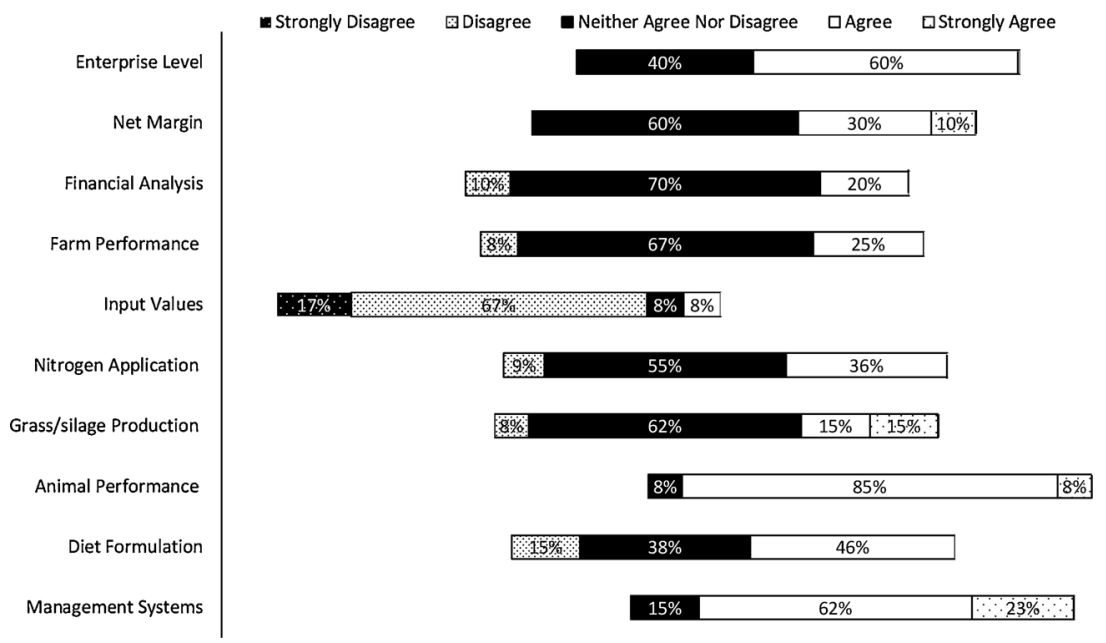

Fig. 3. Workshop questionnaire results. This took place during the Beef, Sheep \& Dairy KT Strategy Group of SAC Consulting and SRUC (2018) and was an attempt to validate the GSBS model by capturing the opinion of knowledgeable individuals. This is the summary of expert's workshop questionnaire results that indicates the extent to which participants agree or disagree with the model's outputs on a 5-point Likert response scale.

capacity, as it enables testing of the resilience of beef finishing systems under diverse market conditions. In an attempt to understand enterprises' financial performance under different pricing schedules, pricing grids from two major beef processors were included. ABP and Dunbia, have pricing grids that reflect the supermarket specifications and consumer preferences, thus providing a lower price for over-age cattle and carcass weights in excess of specific thresholds. The model included age penalties for cattle over 30 months, as well as weight penalties for carcasses outside latest specifications (Dunbia, 2015; Robert Forster, 2015).

Pricing data were collected from various sources including Farm Management Handbook (2016), websites, publications from Scottish Government and personal communication with SAC Consultants (AHDB Beef and Lamb, 2018; Ashworth, 2009; ERSA, 2016; Hyslop et al., 2016; SAC Consulting, 2017; Scottish Government, 2014; The Scottish Government, 2015a, 2015b, 2008). Less critical prices were adopted from Ashfield (2014), converted form Euro to Pound Sterling (OFX Group Ltd, 2018) and adjusted for inflation according to a process described by the Bank of England (Bank of England, 2018).

Variable costs typically include concentrate, fertiliser, silage making (contractor, additives and polythene), veterinary and medicine, reseeding, straw, slurry spreading, milk replacer, interest on working capital, market and abattoir costs, transport costs and land rental (Ashfield et al., 2013). Data from Scottish Government were collected to estimate land rental for different areas of Scotland, to account for the large variation encountered (The Scottish Government, 2015b). Fixed costs included expenses like electricity, car, phone, land improvements maintenance and interest on an assumed long term loan. Other fixed costs included, machinery operating, building maintenance, and the corresponding depreciation, plus interest on machinery and land improvements. The initial method for calculating the cost of the buildings and machinery was described by (Ashfield et al., 2013). It was also assumed that the machinery owned by the farmer included a tractor and static machinery for routine field operations (e.g. fertiliser spreading and grass topping), while operations like grass silage harvesting, reseeding and slurry spreading were carried out by a contractor. The interest rate for long term borrowing was set at 8\%, including investments on land improvements, accommodation for animals during the indoor period and machinery. Paid labour was included in the fixed costs. Average labour hours per month for different categories of beef finishing system, as well as rates for skilled and casual agricultural labour for Scotland were used (Nix and Redman, 2016; SAC Consulting, 2017). The model does not account for the opportunity cost of owned land, or for unpaid family labour. The main output from the financial sub model is the monthly and annual cash flow and annual profit and loss account.

\section{Model validation}

Farm systems models are difficult to validate formally due to lack of independent datasets, and therefore are often evaluated using a panel of experts (Crosson et al., 2006a). As a result of the absence of a robust dataset for Scottish beef finishing systems, the process selected for evaluating the model was "face validity" by "knowledgeable individuals" as described by various authors (Qureshi et al., 1999; Rykiel, 1996; Sargent, 2010). During the design process for the GDBSM, regular consultations with researchers at Teagasc, Grange Research Centre were taking place, to ensure that the proper biological relationships were specified and to validate coefficients used in the model (Crosson et al., 2006a).

A workshop to evaluate the GSBM took place with the Beef, Sheep \& Dairy KT Strategy Group of SAC Consulting and SRUC. Thirteen knowledgeable individuals (e.g. beef specialist consultants, grass specialists, professors, farm managers, researchers) were present for the workshop, which purpose was to gain feedback from beef experts regarding the model's performance and accuracy. Workshop activities involved presenting the model's structure, testing several scenarios (e.g. resources, input prices and performance indicators), and completing a questionnaire with twelve questions using a 5-point Likert response scale to measure how well they agree with model's outputs (Likert, 1932). The questionnaire also included open questions on the model's outputs. Workshop results are summarised in Fig. 3.

Although, the model appeared to accurately depict animal performance of continental breeds in Scotland; there were aspects that needed recalibration. The model was not accurate for the current financial situation of Scottish beef enterprises. In response to survey results, individual sessions were held with SAC consultants, where new values were estimated for input prices, and it was decided to include beef prices only for years 2015-17; excluding previous years with extreme volatility affecting the mean (The Scottish Farmer, 2018). Also, the equation used for grass production estimation was decreased by $20 \%$, along with option for second cut silage, which was decreased by the same amount for yield (t DM/ha) and dry matter digestibility $(\mathrm{g} / \mathrm{kg})$. After recalibrating the model, beef experts were contacted again and after a series of consultations aiding both to model verification and model validation process, they were content that GSBM was simulating beef finishing systems in Scotland within an acceptable range of technical and financial outputs.

Sensitivity analysis is the process of recalculating outcomes under alternative assumptions to determine the impact of an input variable and is considered critical to model validation (Pianosi et al., 2016). For 
the purpose of identifying which inputs cause significant uncertainty and testing the robustness of the model, sensitivity analysis was performed for a beef finishing system slaughtering heifers at 24 months of age. The main inputs examined were carcass prices, concentrate costs and yearling values (Fig. 10).

\section{Model application}

GSBM was used to investigate the technical and economic performance of the most common beef production systems in Scotland. Scenarios involved finishing either male or female animals on a range of finishing ages for each of three distinct treatments, whereby cattle were slaughtered at monthly intervals of 14-17, 18-24 and 25-35 months of age ('short', 'medium' and 'long' durations respectively). Implications for the systems' financial performance were of interest because the management approaches varied greatly in inputs and outputs. Land area was constrained to 120 ha, typical for a beef finishing farm in Scotland. Likewise, the inorganic nitrogen input on the grazing area was fixed at $175 \mathrm{~kg} \mathrm{~N} /$ ha across the different systems. Additional nitrogen quantity, which was attributed to extra concentrates, $\mathrm{N}$ mineralisation (i.e. from the soil) and potentially from $\mathrm{N}$ fixation by legumes, was assumed to enter the farm system on a yearly basis. All livestock were purchased as yearlings and the number of animals was matched to land area and forage production. For the shorter duration finishing systems, only one silage cut harvest date was modelled, on 29th May. In contrast, for the medium and longer pasture based systems, two silage cuts were assumed with 6 weeks of regrowth.

\subsection{Scenario analysis}

In order to examine the resilience of Scottish beef production systems, scenarios based on altering factors that affect financial outcome were constructed and investigated. These illustrate two different approaches: scenarios about finishing duration, choice of animal's gender, feed efficiency and within-herd variation take a bottom-up approach driven by what the farmer might be able to change, while the ones concerning a simulated governmental financial aid have a top-down approach, directed from the administrative authorities and what they might do to make up incomes.

Scenario 1. The first scenario explored the effect of different finishing durations on farm's profitability. Several authors have identified system intensity variation in finishing durations to be a vital determinant of profitability for beef systems (French et al., 2001; Keane and Allen, 1998; Keane et al., 2006). The GSBM was employed to determine the cost-effectiveness of different management practices and slaughter ages (at monthly intervals) for beef finishing systems. The most common beef finishing systems in Scotland were reflected in the different treatments (i.e. 'short', 'medium' and 'long' duration).

Scenario 2. The second scenario considered the effect of using different genders on profitability. It has been shown previously that steers consume more feed, gain weight faster, and are more efficient than heifers. Hence, steers tend to be more profitable than heifers (Koknaroglu et al., 2005). However, variation in sale prices, feeder prices, and feed conversion rates are also significant in explaining possible differences in steer and heifer profitability over time (Langemeier et al., 1992). Simulation results enabled a comparison between genders, to identify difference in performances for each finishing age.

Scenario 3. The third scenario investigated the effect of genetically selecting cattle for improved feed efficiency. Considerable resources and expenses of a beef enterprise are allocated to the feed budget (McGee, 2014). Consequently, feed efficiency in growing and finishing cattle, which translates as the ability of animals to reach a target body weight with the least amount of feed intake, is a key factor in the beef cattle industry (Cantalapiedra-Hijar et al., 2018). Several studies have attempted to gain an understand into the biological basis governing deviating phenotypes for feed efficiency in bovine by examining animals' blood metabolites and hormones (Bourgon et al., 2017; Cônsolo et al., 2018; Gonano et al., 2014; Richardson et al., 2004), or by studying cattle's hepatic function (Casal et al., 2018; Montanholi et al., 2017). Other studies focused on (Lu et al., 2013), analysing interactions with the rumen microbiome (Paz et al., 2018), associations with meat quality (Herd and Bishop, 2000), or concentrated in the host genomics (Lu et al., 2013; Snelling et al., 2011). Further studies on genetic selection using divergent breeds of cattle from around the world have shown that within any group there could be a variance of around $20 \%$ in feed efficiency between the most efficient and the least efficient animals (Fitzsimons et al., 2014; Grigoletto et al., 2017; Kenny et al., 2014; Lawrence et al., 2012; McGee, 2016; Takeda et al., 2018). GSBM simulated the genetic selection effect for feed efficiency by decreasing the daily energy requirements of animals by $20 \%$ while achieving the same level of live-weight gain. This scenario attempted to simulate the effect of selection across the national herd rather than an individual breeder selecting for feed efficiency, while all animals were bought into the farm.

Scenario 4. The fourth scenario explored effects of within-herd variation in performance related to genetic differences (Jenkins et al., 1991). This scenario simulates the significant amount of animal-to-animal variation that occurs around the average feed efficiency observed in beef cattle reared in similar conditions (Cantalapiedra-Hijar et al., 2018). Intra-population genetic variation can have a long-term impact on genetic change for various productivity objectives. This approach is often used to complement the quicker and more targeted genetic selection between breeds, which was simulated in Scenario 3 (Jakubec et al., 2003). To formulate this scenario to effectively portray intra-herd selection outcomes, the best performing animals within the group were identified and the model then assumed that all animals of the herd share these characteristics.

Scenarios $5 \& 6$. For the fifth and the sixth scenario, technical variability of prevalent beef finishing systems in Scotland was compared alongside the fixed effect of policy changes regarding a direct support payments scheme, simulating the current level of EU support payments. Age at slaughter profiles for cattle were retrieved from the Red Meat Industry Profile, which showed that during 2017, the most common systems for both steers and heifers in Scotland were finishing cattle at 24 months (Quality Meat Scotland, 2018). Hence, 24-month finishing systems were used as the baseline for this modelling analysis. The current farmer support payments from the European Union were included; these are land-based and non-enterprise specific subsidies, aimed at supporting environmental, economic and rural development (SAC Consulting, 2017). The effect of policy change regarding financial support on a range of financial performance of beef farms in Scotland was examined using a stochastic analysis for two different scenarios using Monte Carlo simulation. One scenario excluded, and the other included, the current level of subsidies available for beef enterprises. Monte Carlo simulation, a method of risk assessment, was applied to measure the uncertainty generated by input values and carcass prices (Fig. 4).

\section{Results}

\subsection{Scenario 1}

Levels of applied organic nitrogen exceeded the level of $250 \mathrm{~kg} \mathrm{~N} /$ ha allowed by UK regulations (The Scottish Government, 2008) for some systems (e.g. 14- and 15-month systems) and these were rejected as non-compliant. Only thirteen of the forty systems examined were found to be profitable without subsidies. With steers the least profitable systems were the longer finishing ones, with the largest loss of £563/ animal reported for the 35 month finishing system. The most profitable system was the medium finishing at 18 months, with a profit of $£ 169$ / animal. For the short duration systems, diet was set to only include 


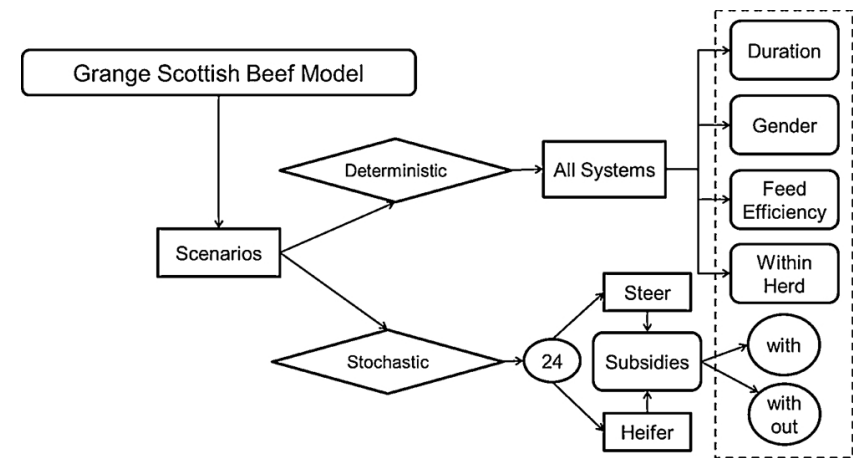

Fig. 4. GSBM scenarios for determining the profitability on Scottish beef finishing systems. The scenarios simulated by the model were divided in deterministic and stochastic. Deterministic simulations: Examines systems of either steers or heifers, along with three different finishing durations ('short', 'medium', 'long') for each. Systems' profitability is examined with scenarios comparing between the financial performance of two genders (Scenario 1) and finishing durations (Scenario 2). In addition, the profitability of base results produced by the model were studied against scenarios employing animals genetically improved for feed efficiency (Scenario 3), as well as animals improved via intra-herd selection (Scenario 4). Stochastic simulations: Examines systems taking into consideration the probabilistic nature of agricultural inputs (Scenario 5 and Scenario 6). Systems' profitability is examined with scenarios concerning both genders (steers and heifers), but are focused on finishing duration of 24 months. Scenarios examined an enterprises' financial performance with and without governmental support payments (subsidies).

silage and concentrates, thus, the model assumed that these types of systems could sustain a great number of animals, depicting larger intensive feedlot-type beef finishing enterprises. For the heifer finishing systems, positive net margins were reported for short duration systems, with 16 and 17 month systems both generating profits of $£ 134$ per animal. Low financial returns were evident for long duration systems, with the 34 and 35 month systems reporting heavy losses (net margins of $-£ 459$ and $-£ 523$ per animal respectively). Further details for each gender and finishing duration are provided in Supplementary Material.

\subsection{Scenario 2}

Steers showed higher financial returns than heifer systems in 17 out of the 20 different cases compared (Fig. 5). Exceptions were noted when slaughtering at 30, 34 and 35 months of age, where heifer systems were more profitable. The largest difference between the two genders, $£ 82$ per animal, was recorded for 16 month finishing systems.

\subsection{Scenario 3}

Impacts of selecting for feed efficiency on farm profitability were analysed for both steer and heifer systems. Unsurprisingly, net margins increased for all systems examined and five systems, (steers slaughtered at 23 and 24 months, and heifers slaughtered at 22, 23 and 24 months) transformed from loss making to profitable. The full analysis of the effects of increasing feed efficiency for steers and heifers on systems with different finishing duration is presented on Fig. 6 . The impact of feed efficiency is greater in steers than heifers, and becomes more pronounced with longer finishing durations.

\subsection{Scenario 4}

In Fig. 7 financial results for the highest growth rate animals in each group are compared with the average performing animals. There is potential to increase margins with better performing animals of the same breed and sex, especially on short and medium duration fattening systems. The influence of within-herd performance variation delivered the highest increase on net margin in 17 month system for steers and in 24 month system for heifers. The positive effect a high level of growth has on profitability decreases the longer the animals are kept in a system for both steers and heifers (though at different rates). It was interesting to compare on selection between the two sexes, as it had a large effect on profitability, especially for the longer duration systems with heifers. Fig. 8 shows the comparison between the two genders and highlights the move to slightly more profitable heifer systems on longer finishing durations.

\subsection{Scenarios $5 \& 6$}

Distributions of net margin levels for 1000 simulations of 24 month steer systems, with or without financial support provided by the state are presented on Fig. 9. An enterprise without receiving economic aid was calculated to generate a loss of $£ 69 /$ animal, with a standard deviation of $£ 52 /$ animal. The likelihood of a farm making profit was only $9 \%$. When financial support was included the mean shifted to producing a profit of $£ 13 /$ animal, with a standard deviation of $£ 51$ /animal. After the incorporation of state economic relief the probability of a farm recording loss was reduced to $39 \%$. Following the same methodology, distributions of net margin for the 24 month heifer systems with and without financial aid were calculated. Results were similar with the steer systems, with mean net margin for the examined scenario was

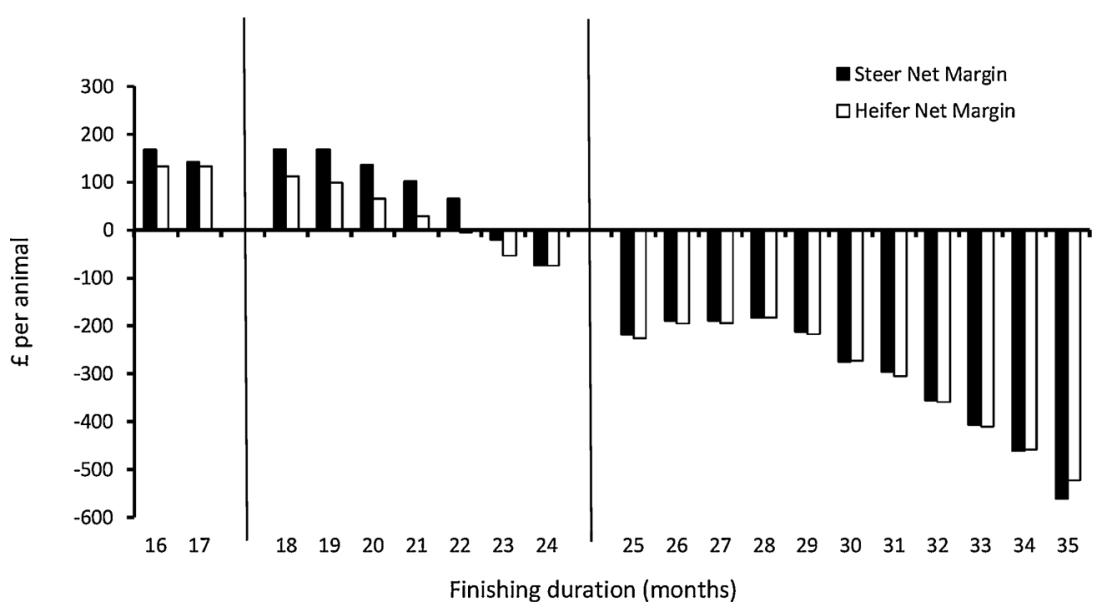

Fig. 5. Comparing financial performance in terms of net margins ( $£$ /animal) for steer and heifer systems (Scenario $1+$ Scenario 2). Scenarios include a range of finishing ages for each of three distinct treatments, by which animals were finished at monthly intervals of 14-17, 18-24 and 25-35 months of age ('short', 'medium' and 'long'). 


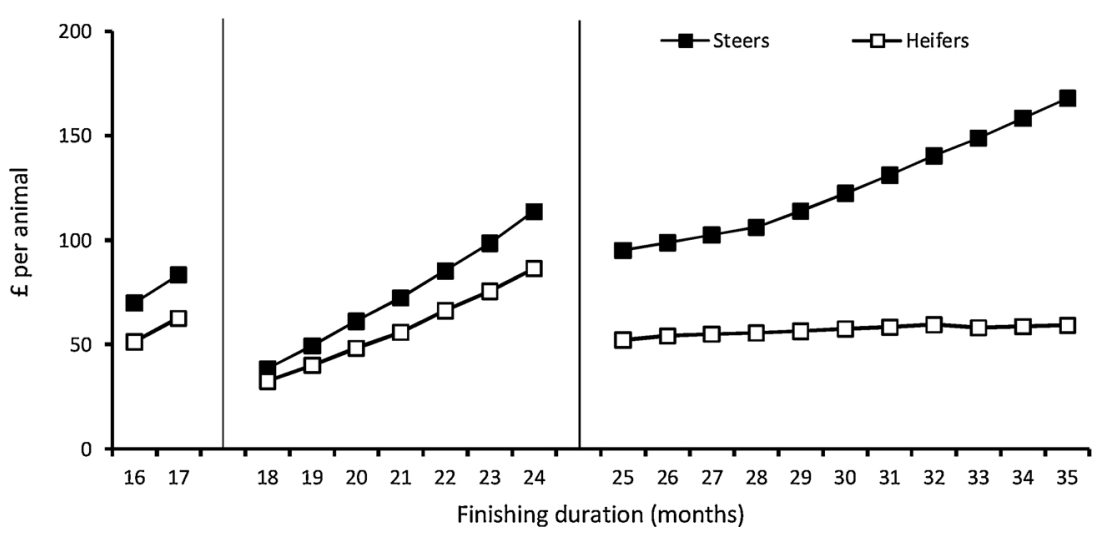

Fig. 6. Improvement of profitability as a result of genetic selection on feed efficiency on steers and heifers (Scenario 3). Animals were finished managed to finish at monthly intervals of 14-17, 18-24 and 25-35 months of age ('short', 'medium' and 'long'), with x-axis represents increasing finishing durations.
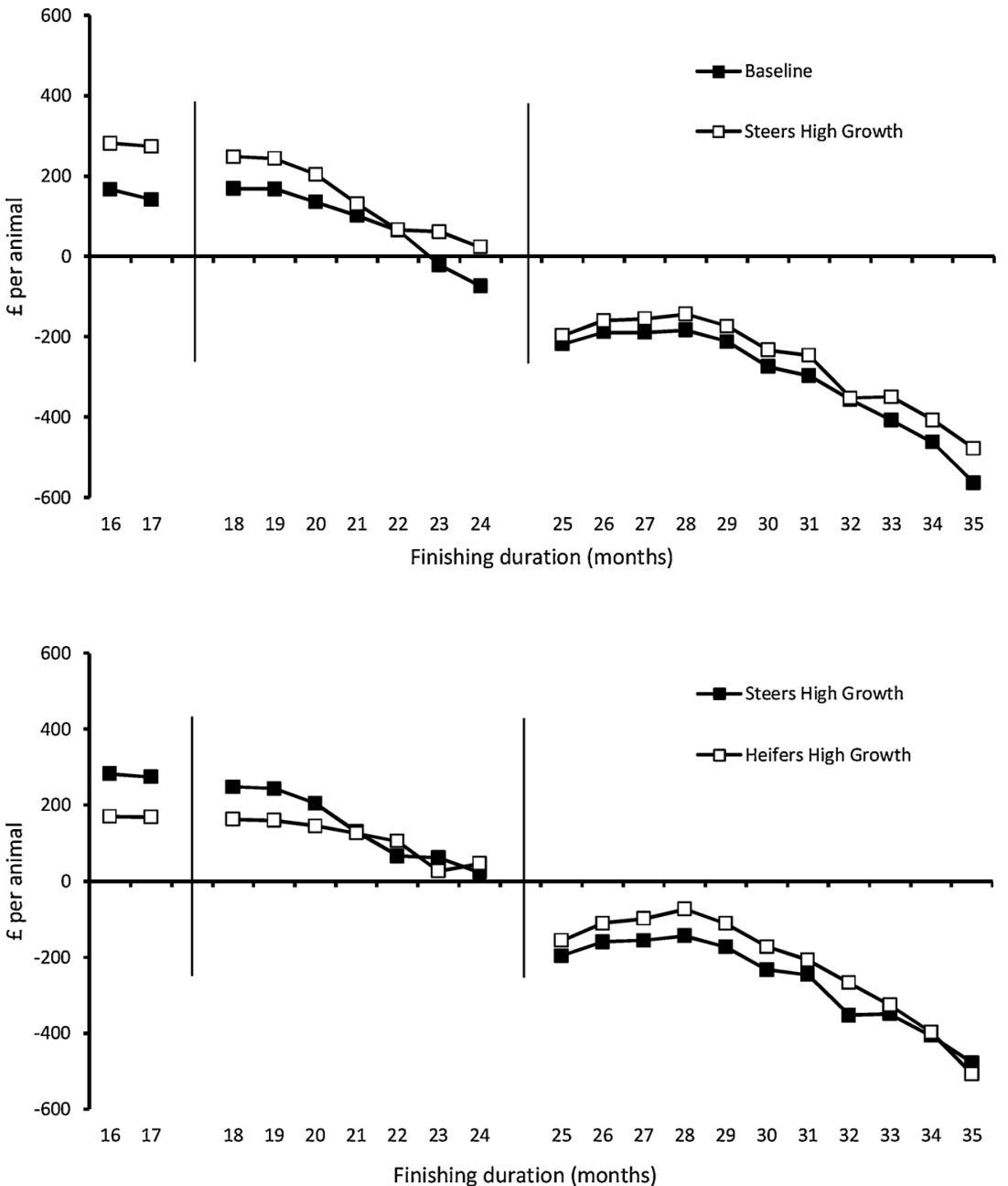

Fig. 7. Comparison of financial performance in terms of net margins ( $£$ /animal) for average and high growth steer systems (effects of within-herd variation on profitability) (Scenario 4). Scenarios include a range of finishing ages for each of three distinct treatments, by which animals were finished at monthly intervals of 14-17, 18-24 and 25-35 months of age ('short', 'medium' and 'long').
Fig. 8. Comparison of financial performance in terms of net margins ( $£$ /animals) between steer and heifer systems with animals improved via intra-herd selection. Scenarios include a range of finishing ages for each of three distinct treatments, by which animals were finished at monthly intervals of 14-17, 18-24 and 25-35 months of age ('short', 'medium' and 'long'). likely to be a loss. The probability of an enterprise recording positive net margins was as low as $2 \%$. In contrast, when governmental fiscal aid was included only a $33 \%$ of the simulation runs generated loses. Although, these results look promising for both steers and heifers, there is still a significant chance that the system would record losses, even with after the current level of financial support provided to beef enterprises was included.

Fig. 10 reports the results of sensitivity analysis carried out for finishing heifers at 24 months on net margin change in response to a $25 \%$ variation in yearling price, concentrate cost and carcass value. Net margin calculated using the model values reported above resulted in a loss of $£ 75 /$ heifer. Further analysis revealed that the greatest effect on system profitability is attributed to carcass prices variation. The effect of shifting carcass prices on net margin variance was $£ 655 / a n i m a l$, while the effect of yearling costs and concentrates costs was $£ 321$ and $£ 63$ per animal, respectively. This analysis suggest that for the 24 month heifer system to generate a profit, yearling prices would need to decrease by $15 \%$, carcass prices would need to increase by $10 \%$, or there would be need to be a more than $25 \%$ decrease in concentrate costs. 


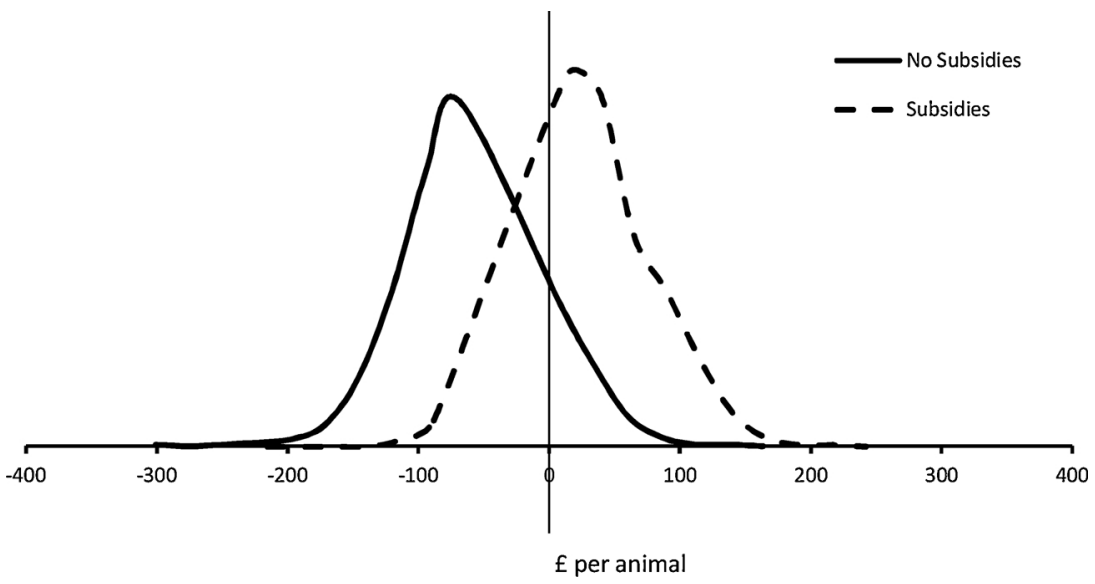

Fig. 9. Results indicating the effect of the current governmental support payments scheme of 24 months steer system. Enterprise performance in Scenario 5 and Scenario 6 was examined by employing stochastic analysis (Monte Carlo simulation). Similar results were obtained for the 24 month heifer system.

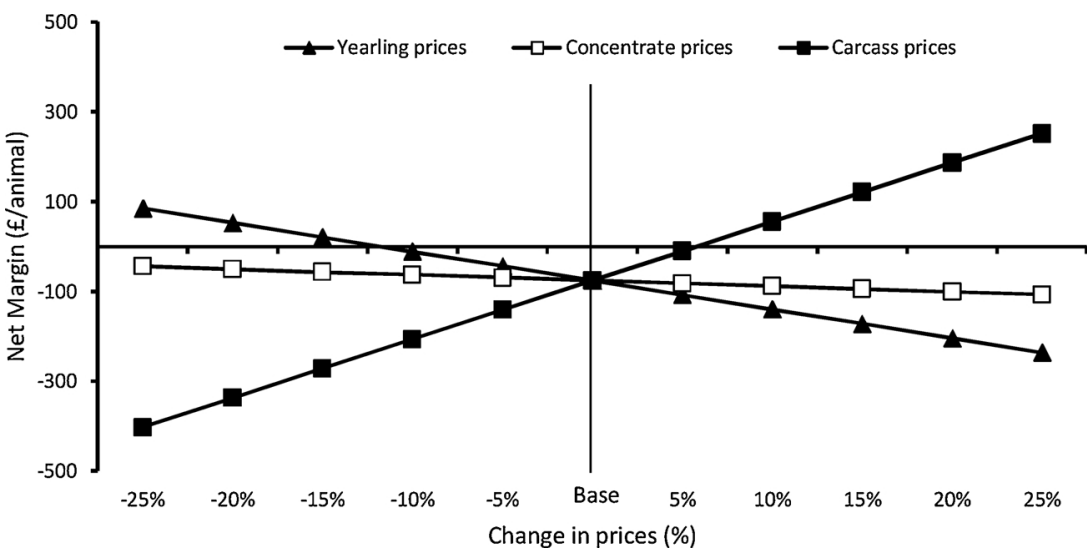

Fig. 10. Sensitivity analysis studying the uncertainty regarding key input prices and the robustness of the GSBM. Results show the effects of variation in prices (yearlings; concentrates; carcass) on net margin from a 24 months heifer finishing system.

\section{Discussion}

\subsection{General discussion}

A model for simulating beef finishing systems has been developed and Scotland was used as a case study. GSBM considers the complex relationships between enterprise efficiency, farm capacity and animal performance. Several finishing systems relevant to Scottish conditions were simulated, and their financial performance was investigated under different economic scenarios.

Beef finishing operations decide on livestock to purchase considering the corresponding beef prices. Steer systems were found to be more profitable than heifer systems for continental breeds in Scotland. Continental steers tend to grow faster and producing heavier carcasses than heifers, resulting in a greater carcass output per area farmed (Steen and Kilpatrick, 1995). At the same time, heifers deposit fatty tissue quickly and it has a direct impact on their carcass profile and value (Keane and Drennan, 1987). The most cost-effective systems were the 18 and the 16 month slaughtering age for steers and heifers respectively. However, there are limitations to this simulation exercise, as the figures employed represent only one production cycle, due to restrictions on available datasets for Scotland. Another reason for caution is that in the current exercise grazing was excluded from shorter finishing duration systems, while a relatively large number of animals were assumed. All systems were based on the same available farming area, and simulate the most common slaughtering age options. Each system can be analysed in depth using the model highlighting its unique advantages and drawbacks, but these were considered to be outside the scope of this paper, where the performance and accuracy of a new model are being discussed. For example, despite the apparent advantages for animal performance and profitability when mainly on concentrate based diets, there are niche markets for high value products produced from grass-fed animals that could potentially offer higher returns. Consequently, opportunities for a region like Scotland may be found in the profitable medium term finishing systems, where a proportion of grass is included in the diet as well (AHDB, 2016).

When selecting for feed efficiency or including the current level of financial aid provided by the government, all systems benefited from the positive effect, while in some cases the influence proved to be critical, as it allowed systems to generate profit. Considerable genetic variation exists in beef cattle for feed efficiency, unaccounted for by differences in weight and growth rate (Fitzsimons et al., 2014; McGee, 2016). The use of plausible decrease in animal daily energy requirements derived from expert knowledge and guided by available literature may be considered inferior to a complex bio-economic model. However, instead of aiming for a detailed understanding of biophysical processes underpinning feed efficiency in cattle (Pitchford, 2004), this paper investigates the potential range of variation in net margins associated with genetically select animals for feed efficiency changes for representative farms in a study region. Opportunities to improve the profitability of beef production systems occur when focusing on producing selection tools that incorporate biological and economic parameters to support breeding programs. Cattle that were bred for feed efficiency were found to have multiple benefits, such as decreased DMI, 
less manure production, and less emission of methane, thus; minimizing their environmental impact (Cantalapiedra-Hijar et al., 2018; Fitzsimons et al., 2014; Hegarty et al., 2007; Nkrumah et al., 2006). Within-herd variation in animal growth rates had a substantial impact on profitability of individuals. When comparing economic performance with the effect, margins increased noticeably for both steers and heifers, especially for the longer duration heifer systems. Although, different breeds can be selected to optimize performance levels for growth traits more quickly than through selection within breeds, it might be a useful tool when used concurrently. It is argued that within herd variation should have the largest long term impact on genetic change for particular aims (Jakubec et al., 2003).

While, a system's performance may appear to be promising when applying average values, investigating its resilience and adaptability using stochastic analysis is crucial for gaining confidence in the predicted results (Villalba et al., 2006). During the analysis of the 24 month steer and heifer finishing systems, there were 39\% and 33\% chances of recording losses, despite adding basic grants. The rural schemes examined in this paper were the Basic Payment Scheme available to Scotland along with the Greening payments; both part of European Union Common Agricultural Policy (Pillar 1 - Direct payments). This study simulated the possible effects of changes in domestic policy agricultural policy, in the form of reinstating or maintaining a form of direct payments, would have on the profitability of beef finishing enterprises. The total abolition of CAP-related financial aid for Scottish beef farms presents only one of the factors that are considered to shape the future landscape of the UK's agri-sector. In fact, measuring the possible consequences on agriculture is itself a complex and multifaceted task that requires extensive research in scenario developing (Davis et al., 2017; Feng et al., 2017; Harvey et al., 2019; Hubbard et al., 2018). It is worth noting that although there is some uncertainty associated with the UK leaving the European Union the UK government has pledged to keep overall payments to the same level until 2022 (SAC Consulting, 2017). These systems are highly reliant on direct payments schemes and given the economic status of agri-sector in Scotland, policy mechanisms should be in place to protect livestock systems from severe economic shocks.

\subsection{Innovations of approach and other models}

The GSBM facilitates a detailed economic analysis that leads to evaluating the performance of Scottish beef enterprises. This could contribute to developing a deeper understanding of complex relationships that govern beef production systems. This paper builds on previous studies on feed efficiency by exploring the effects of breeding for feed efficiency along with effects of within-herd variation on financial performance (Hill, 2012; Kenny et al., 2018). Furthermore, knowledge gained could be employed to guide the design of novel systems, so as to be in a position to sustain self-sufficient and cost-effective enterprises. Afterwards, the model could analyse the profitability of newly designed systems and compare it with the existing ones. By constructing and analysing a range of scenarios, GSBM supports a framework for investigating multiple effects of alternative policies, market and production conditions on profitability. This model simulates economic conditions for the livestock sector, while including a variety of options on genders, finishing ages and feeding strategies, to provide a relevant flexibility when determining profitable systems or identifying areas that could cause a system to underperform. Also, the model supports an array of sensitivity and Monte Carlo simulation analysis, while retaining the option of modifying input/output values as well as performance parameters.

\subsection{Limitations of approach and future research}

In principle, the GSBM is a general simulation model that can be employed for the evaluation of beef production systems in Scotland. Nevertheless, it is highlighted in the literature that simulation models are not able to represent a real system completely and hence, they will have to be constantly improved (Gradiz et al., 2007). In addition, when developing a general model there will be a trade-off between a more practical approach for less accuracy and precision (Hirooka et al., 1998). The model was able to take into account the variability created by fluctuation in prices. However, various areas that could significantly influence the model behaviour are yet to be fully studied and included, for example animal performance, energy demands, grazed grass and grass silage yields. Another constraint for the model was that the dataset employed, though it described typical Scottish systems, it included only one beef production cycle; therefore, limitations involve exclusion of plausible year-to-year variation. Additionally, to further investigate implications of breed selection on farms' profitability, other breeds with different performance characteristics (e.g. Aberdeen Angus or Luing) should be included in the model.

Future research ought to focus on potential environmental factors and their effect on system profitability, an area of great interest in the last decades because of the collective effort to mitigate the greenhouse gas (GHG) emissions attributed to beef production sector (Bellarby et al., 2013; Foley et al., 2011; Lesschen et al., 2011). Beef production is considered to have a substantial environmental footprint, contributing around $41 \%$ of the entire livestock sector emissions (Gerber et al., 2015, 2013; Poore and Nemecek, 2018). Several studies point out to the fact that feedlot-based short duration beef finishing systems have lower land requirements and GHG emissions per kilogram of meat compared to longer duration grass-based systems (Bragaglio et al., 2018; Capper, 2012; Nguyen et al., 2010; Peters et al., 2010). Nevertheless, grazing ruminant production systems provide ecosystem services (Dick et al., 2016), have a positive effect on long-term soil fertility (Horrocks et al., 2014) and a high potential for carbon sequestration (Conant et al., 2017), along with numerous health benefits that have been attributed to moderate consumption of grass-fed beef in comparison to concentrate-fed beef (Warren et al., 2008). The growing meat demand of an expanding human population, coupled with the challenges of global climate change, highlight the importance of exploring alternative beef production systems that have the potential to reduce environmental impacts from meat production and to guarantee long-term food security (Alexander et al., 2015; Eisler et al., 2014; Swain et al., 2018). The model described in this study has the potential to be employed in further livestock systems research for investigating environmental and economic scenarios, to enhance understanding of current systems and explore alternative strategies to address both low profitability and potential GHG mitigation.

\subsection{Broader implications}

In this paper, the region of Scotland was employed as a case study to demonstrate the capabilities of the GSBM. While in some cases, results from the GSBM were found to be relevant to beef production systems in other areas of the temperate climate zone, this approach focused on the highlighting the region's unique conditions. However, the methodology employed to calculate financial outcomes of beef finishing farms in GSBM was designed to be universally applicable. Inputs such as livestock live weights, growth rates and, ration composition will differ between regions, but the core methodology of the approach was not specific to a particular geographic region. Consequently, the same approach that was used to localize the model for Scotland could be employed to simulate beef finishing systems in other contexts and regions. In addition, GSBM could further assist the on-going efforts to breed cattle for feed efficiency, as it has the potential to examine scenarios simulating the effects of such efforts on farm's profitability.

\section{Conclusion}

The GSBM simulated the physical and financial performance of Scottish beef finishing systems. It was demonstrated that it can be used 
to analyse current and future scenarios of interest. The model offers the user the opportunity to gain insights and tests various managerial options about the beef fattening stage. Profitable opportunities for finishing late-maturing cattle in Scotland were identified by investigating alternative finishing durations for different systems. It was more costeffective to finish cattle on shorter or medium duration systems. Another crucial decision with economic impact would be the choice of livestock gender. Steers were more profitable than heifers on most occasions, especially for the short and medium length systems. In addition, the range of profit that specialized breeding could deliver to farmers was presented for different systems via simulating the effects of improving the cattle's feed efficiency and within herd performance variation. These insights could contribute in making an informed decision regarding aspects of beef production that are under the farmer's control.

It is anticipated that the model will be employed to construct agricultural policy, as well as market and production related scenarios. The model identified the level of dependence on EU's financial aid, along with the effects of carcass and store price volatility on profitability for the most popular fattening systems in Scotland. It becomes pressing in the face of the latest political developments to further investigate the sector's dependence on receiving governmental fiscal support and adopt systems that would prove more reliant and welladjusted to each region's strengths. Therefore, model outcomes could be then used to reduce costs or increase productivity to make systems more profitable. The methodology described can be employed to tailor the model for other regions.

\section{Acknowledgements}

The authors would also like to thank the research community within SRUC, SAC Consulting and AHDB for providing feedback during the development of this project. In addition, the financial assistance for one of the authors (C. Kamilaris) through SRUC PhD studentship and Teagasc Walsh Fellowship and is also acknowledged. BVA's contribution to this research was funded by the Scottish Government's Strategic Research Programme 2016-2021, Theme 2, Work package 2.4 Rural Industries.

\section{Appendix A. Supplementary data}

Supplementary material related to this article can be found, in the online version, at doi:https://doi.org/10.1016/j.agsy.2019.102713.

\section{References}

Agriculture and Horticulture Development Board (AHDB), 2017. Meat and Dairy - Our Prospects in the Global Marketplace.

AHDB, 2016. What might Brexit mean for UK trade in agricultural products? Horiz. Mark. Intell. 1-44.

AHDB Beef \& Lamb, 2018. Weekly GB Regional Averages. AHDB Beef \& Lamb. [WWW Document]. http://beefandlamb.ahdb.org.uk/markets/auction-market-reports/ weekly-gb-regional-averages/. (Accessed 6.4.18).

Alexander, P., Rounsevell, M.D.A., Dislich, C., Dodson, J.R., Engström, K., Moran, D. 2015. Drivers for global agricultural land use change: the nexus of diet, population, yield and bioenergy. Glob. Environ. Chang. 35, 138-147. https://doi.org/10.1016/j. gloenvcha.2015.08.011.

Allen, P., 2014. Beef carcass classification and grading. Encyclopedia of Meat Sciences. https://doi.org/10.1016/B978-0-12-384731-7.00060-X.

Antle, J.M., Basso, B., Conant, R.T., Godfray, H.C.J., Jones, J.W., Herrero, M., Howitt, R.E., Keating, B.A., Munoz-Carpena, R., Rosenzweig, C., Tittonell, P., Wheeler, T.R., 2017. Towards a new generation of agricultural system data, models and knowledge products: design and improvement. Agric. Syst. 155, 255-268. https://doi.org/10. 1016/j.agsy.2016.10.002.

Ash, A., Hunt, L., McDonald, C., Scanlan, J., Bell, L., Cowley, R., Watson, I., McIvor, J., MacLeod, N., 2015. Boosting the productivity and profitability of northern Australian beef enterprises: exploring innovation options using simulation modelling and systems analysis. Agric. Syst. 139, 50-65. https://doi.org/10.1016/j.agsy.2015.06.001.

Ashfield, A., 2014. A Mathematical Model of Dairy Calf-to-Beef Production Systems. Thesis.

Ashfield, A., Crosson, P., Wallace, M., 2013. Simulation modelling of temperate grassland based dairy calf to beef production systems. Agric. Syst. 115, 41-50. https://doi.org/ 10.1016/j.agsy.2012.10.001.

Ashfield, A., Wallace, M., Crosson, P., 2014a. Economic comparison of pasture based dairy calf-to-beef production systems under temperate grassland conditions. Int. J. Agric. Manag. 03. https://doi.org/10.5836/ijam/2014-03-06.

Ashfield, A., Wallace, M., McGee, M., Crosson, P., 2014b. Bioeconomic modelling of compensatory growth for grass-based dairy calf-to-beef production systems. J. Agric. Sci. 152, 805-816. https://doi.org/10.1017/S0021859613000531.

Ashfield, A., Wallace, M., Prendiville, R., Crosson, P., 2014c. Bioeconomic modelling of male Holstein-Friesian dairy calf-to-beef production systems on Irish farms. Irish J. Agric. Food Res. 53, 133-147.

Ashworth, S., 2009. The importance of livestock production to the Scottish economyr. Quality Meat Scotland.

Bank of England, 2018. Inflation. Bank of England. [WWW Document]. URL https:// www.bankofengland.co.uk/monetary-policy/inflation. (Accessed 6.4.18).

Bell, M.J., Cloy, J.M., Topp, C.F.E., Ball, B.C., Bagnall, A., Rees, R.M., Chadwick, D.R., 2016. Quantifying $\mathrm{N}_{2} \mathrm{O}$ emissions from intensive grassland production: the role of synthetic fertilizer type, application rate, timing and nitrification inhibitors. J. Agric. Sci. 1-16. https://doi.org/10.1017/S0021859615000945.

Bellarby, J., Tirado, R., Leip, A., Weiss, F., Lesschen, J.P., Smith, P., 2013. Livestock greenhouse gas emissions and mitigation potential in Europe. Glob. Chang. Biol. https://doi.org/10.1111/j.1365-2486.2012.02786.x.

Bohan, A., Shalloo, L., Malcolm, B., Ho, C.K.M., Creighton, P., Boland, T.M., McHugh, N., 2016. Description and validation of the Teagasc Lamb Production Model. Agric. Syst. 148, 124-134. https://doi.org/10.1016/j.agsy.2016.07.008.

Bonesmo, H., Randby, A.T., 2010. The effect of silage energy concentration and price on finishing decisions for young dairy bulls. Grass Forage Sci. 66, 78-87. https://doi. org/10.1111/j.1365-2494.2010.00765.x.

Bourgon, S.L., Diel de Amorim, M., Miller, S.P., Montanholi, Y.R., 2017. Associations of blood parameters with age, feed efficiency and sampling routine in young beef bulls. Livest. Sci. 195, 27-37. https://doi.org/10.1016/j.livsci.2016.11.003.

Bragaglio, A., Napolitano, F., Pacelli, C., Pirlo, G., Sabia, E., Serrapica, F., Serrapica, M., Braghieri, A., 2018. Environmental impacts of Italian beef production: a comparison between different systems. J. Clean. Prod. 172, 4033-4043. https://doi.org/10.1016/ j.jclepro.2017.03.078.

Bywater, A.C., Cacho, O.J., 1994. Use of simulation models in research. N. Z. Soc. Anim. Prod. Proc. 54, 9-14. https://doi.org/10.1079/BJN19660078.

Cantalapiedra-Hijar, G., Abo-Ismail, M., Carstens, G.E., Guan, L.L., Hegarty, R., Kenny, D.A., McGee, M., Plastow, G., Relling, A., Ortigues-Marty, I., 2018. Review: biological determinants of between-animal variation in feed efficiency of growing beef cattle. Animal 1-15. https://doi.org/10.1017/S1751731118001489.

Capper, J.L., 2012. Is the grass always greener? Comparing the environmental impact of conventional, natural and grass-fed beef production systems. Anim. Open Access J. MDPI 2, 127-143. https://doi.org/10.3390/ani2020127.

Casal, A., Garcia-Roche, M., Navajas, E.A., Cassina, A., Carriquiry, M., 2018. Hepatic mitochondrial function in Hereford steers with divergent residual feed intake phenotypes1. J. Anim. Sci. 96, 4431-4443. https://doi.org/10.1093/jas/sky285.

Conant, R.T., Cerri, C.E.P., Osborne, B.B., Paustian, K., 2017. Grassland management impacts on soil carbon stocks: a new synthesis. Ecol. Appl. 27, 662-668. https://doi. org/10.1002/eap.1473.

Cônsolo, N.R.B., Munro, J.C., Bourgon, S.L., Karrow, N.A., Fredeen, A.H., Martell, J.E., Montanholi, Y.R., 2018. Associations of Blood Analysis with Feed Efficiency and Developmental Stage in Grass-Fed Beef Heifers. Anim. Open Access J. MDPI 8. https://doi.org/10.3390/ani8080133.

Crosson, P., O'Kiely, P., O'Mara, F.P., Wallace, M., 2006a. Investigating development options for Irish suckler beef producers using mathematical programming. Farm Manag. 12, 369-383.

Crosson, P., O'Kiely, P., O'Mara, F.P., Wallace, M., 2006b. The development of a mathematical model to investigate Irish beef production systems. Agric. Syst. 89, 349-370. https://doi.org/10.1016/j.agsy.2005.09.008.

Crosson, P., Pi, P.C., Ashfield, A., Wallace, M., 2015. The Development and Application of a Simulation Model of Dairy Calf-to-beef Production Systems. Teagasc Publications, Oak Park, Carlow, Ireland, pp. 1-4.

Davis, J., Feng, S., Patton, M., 2017. Impacts of Alternative Post-brexit Trade Agreements on UK Agriculture: Sector Analyses Using the FAPRI-UK Model.

Dick, J., Andrews, C., Beaumont, D.A., Benham, S., Dodd, N., Pallett, D., Rose, R., Scott, T., Smith, R., Schäfer, S.M., Turner, A., Watson, H., 2016. Analysis of temporal change in delivery of ecosystem services over 20 years at long term monitoring sites of the UK Environmental Change Network. Ecol. Indic. 68, 115-125. https://doi.org/ 10.1016/j.ecolind.2016.02.021.

Dunbia, 2015. Dunbia to Make Changes to UK Beef Carcass Specifications. Agriland.iE. [WWW Document]. URL http://www.agriland.ie/farming-news/dunbia-to-makechanges-to-uk-beef-carcass-specifications/. (Accessed 6.18.18).

Eisler, M.C., Lee, M.R.F.F., Tarlton, J.F., Martin, G.B., Beddington, J., Dungait, J.A.J., Greathead, H., Liu, J., Mathew, S., Miller, H., Misselbrook, T., Murray, P., Vinod, V.K., Saun, R., Van Winter, M., 2014. Steps to sustainable livestock. Nature 507, 32-34. https://doi.org/10.1038/507032a.

ERSA, 2016. The Economic Report on Scottish Agriculture. 2016th ed. Scottish Exec, Edinburgh.

Farmers Guardian, 2017. First Cut Silage Not Completed in Some Parts of Scotland after Dismal Summer. NEWS, Farmers Guardian. [WWW Document]. URL https://www. fginsight.com/news/news/first-cut-silage-not-completed-in-some-parts-of-scotlandafter-dismal-summer-41561. (Accessed 6.4.18).

Feng, S., Patton, M., Binfield, J., Davis, J., 2017. 'Deal' or 'No deal'? Impacts of alternative post-brexit trade agreements on UK agriculture. Euro Choices 16, 27-33. https://doi. org/10.1111/1746-692X.12171. 
Finneran, E., Crosson, P., O’Kiely, P., Shalloo, L., Forristal, P.D., Wallace, M., 2012. Economic modelling of an integrated grazed and conserved perennial ryegrass forage production system. Grass Forage Sci. 67, 162-176. https://doi.org/10.1111/j.1365 2494.2011.00832.x.

Fitzsimons, C., Kenny, D.A., McGee, M., 2014. Visceral organ weights, digestion and carcass characteristics of beef bulls differing in residual feed intake offered a high concentrate diet. Animal 8, 949-959. https://doi.org/10.1017/ S1751731114000652.

Foley, P.A.A., Crosson, P., Lovett, D.K.K., Boland, T.M.M., O'Mara, F.P., Kenny, D.A.A. O’Mara, F.P., Kenny, D.A.A., O'Mara, F.P., Kenny, D.A.A., 2011. Whole-farm systems modelling of greenhouse gas emissions from pastoral suckler beef cow production systems. Agric. Ecosyst. Environ. 142, 222-230. https://doi.org/10.1016/j.agee. 2011.05.010.

French, P., O'Riordan, E., Monahan, F., Caffrey, P., Mooney, M., Troy, D., Moloney, A., 2001. The eating quality of meat of steers fed grass and/or concentrates. Meat Sci. 57, 379-386. https://doi.org/10.1016/S0309-1740(00)00115-7.

Gerber, P.J., Mottet, A., Opio, C.I., Falcucci, A., Teillard, F., 2015. Environmental impacts of beef production: review of challenges and perspectives for durability. Meat Sci. 109, 2-12. https://doi.org/10.1016/j.meatsci.2015.05.013.

Gerber, P.J., Steinfeld, H., Henderson, B., Mottet, A., Opio, C., Dijkman, J., Falcucci, A., Tempio, G., 2013. Tackling climate change through livestock: a global assessment of emissions and mitigation opportunities. Tackling Climate Change Through Livestock: a Global Assessment of Emissions and Mitigation Opportunities. Food and Agriculture Organization of the United Nations (FAO).

Godfray, H.C.J., Beddington, J.R., Crute, I.R., Haddad, L., Lawrence, D., Muir, J.F., Pretty, J., Robinson, S., Thomas, S.M., Toulmin, C., 2010. Food security: the challenge of feeding 9 billion people. Science 327, 812-818. https://doi.org/10.1126/science. 1185383.

Gonano, C.V., Montanholi, Y.R., Schenkel, F.S., Smith, B.A., Cant, J.P., Miller, S.P., 2014. The relationship between feed efficiency and the circadian profile of blood plasma analytes measured in beef heifers at different physiological stages. Animal 8 1684-1698. https://doi.org/10.1017/S1751731114001463.

Gradiz, L., Sugimoto, A., Ujihara, K., Fukuhara, S., Kahi, A.K., Hirooka, H., 2007. Beef cow-calf production system integrated with sugarcane production: simulation model development and application in Japan. Agric. Syst. 94, 750-762. https://doi.org/10. 1016/j.agsy.2007.03.003.

Grigoletto, L., Perez, B.C., Santana, M.H.A., Baldi, F., Ferraz, J.B.S., 2017. Genetic contribution of cytoplasmic lineage effect on feed efficiency in Nellore cattle. Livest. Sci. 198, 52-57. https://doi.org/10.1016/j.livsci.2017.02.009.

Harvey, D.R., Davis, J., Feng, S., Harvey, D., Liddon, A., Moxey, A., Ojo, M., Patton, M., Philippidis, G., Scott, C., Shrestha, S., Wallace, M., 2019. Brexit: How Might UK Agriculture Thrive or Survive? Final Report.

Heaton, K., Kelly, S.D., Hoogewerff, J., Woolfe, M., 2008. Verifying the geographical origin of beef: the application of multi-element isotope and trace element analysis. Food Chem. 107, 506-515. https://doi.org/10.1016/j.foodchem.2007.08.010.

Hegarty, R.S., Goopy, J.P., Herd, R.M., McCorkell, B., 2007. Cattle selected for lowe residual feed intake have reduced daily methane production1,2. J. Anim. Sci. 85, 1479-1486. https://doi.org/10.2527/jas.2006-236.

Herd, R.M.M., Bishop, S.C.C., 2000. Genetic variation in residual feed intake and its association with other production traits in British Hereford cattle. Livest. Prod. Sci. 63, 111-119. https://doi.org/10.1016/S0301-6226(99)00122-0.

Hill, R.A., 2012. Feed Efficiency in the Beef Industry. Wiley-Blackwell, Oxford, UK. https://doi.org/10.1002/9781118392331.

Hirooka, H., Groen, A.F., Hillers, J., 1998. Developing breeding objectives for beef cattle production 1. A bio-economic simulation model. Anim. Sci. 66, 607-621. https://doi. org/10.1017/S1357729800009188.

Hoch, T., Agabriel, J., 2004. A mechanistic dynamic model to estimate beef cattle growth and body composition: 1. Model description. Agric. Syst. 81, 1-15. https://doi.org/ 10.1016/j.agsy.2003.08.005

Hopkins, A., 2000. Grass: Its Production and Utilization. Published for the British Grassland Society by Blackwell Science.

Hornick, J., Van Eenaeme, C., Gérard, O., Dufrasne, I., Istasse, L., 2000. Mechanisms of reduced and compensatory growth. Domest. Anim. Endocrinol. 19, 121-132. https:// doi.org/10.1016/S0739-7240(00)00072-2.

Horrocks, C.A., Dungait, J.A.J., Cardenas, L.M., Heal, K.V., 2014. Does extensification lead to enhanced provision of ecosystems services from soils in UK agriculture? Land Use Policy 38, 123-128. https://doi.org/10.1016/j.landusepol.2013.10.023.

Hubbard, C., Davis, J., Feng, S., Harvey, D., Liddon, A., Moxey, A., Ojo, M., Patton, M., Philippidis, G., Scott, C., Shrestha, S., Wallace, M., 2018. Brexit: how will UK agriculture fare? Euro Choices 17, 19-26. https://doi.org/10.1111/1746-692X.12199.

Hyslop, J., Duthie, C.-A., Richardson, I., Rooke, J., Ross, D., Matthews, K., 2016. Lifetime Growth Pattern and Beef Eating Quality (Growth Path) [WWW Document]. URL http://beefandlamb.ahdb.org.uk/wp-content/uploads/2014/02/61100021-LifetimeGrowth-Pattern-and-Beef-Eating-Quality-FInal-Report-120916.pdf. (Accessed 7.4.18).

Jakubec, V., Schlote, W., Riha, J., Majzlik, I., 2003. Comparison of growth traits of eight beef cattle breeds in the Czech Republic. Arch. Fur Tierzucht-Arch. Anim. Breed.

Jarrige, R., Demarquilly, C., Dulphy, J.P., Hoden, A., Robelin, J., Beranger, C., Geay, Y. Journet, M., Malterre, C., Micol, D., Petit, M., 1986. The INRA "Fill Unit" System for Predicting the Voluntary Intake of Forage-Based Diets in Ruminants: A Review. J. Anim. Sci. 63, 1737-1758.

Jenkins, T.G., Kaps, M., Cundiff, L.V., Ferrell, C.L., 1991. Evaluation of between- and within-breed variation in measures of weight-age relationships. J. Anim. Sci. 69, 3118. https://doi.org/10.2527/1991.6983118x.

Jones, J.W., Antle, J.M., Basso, B., Boote, K.J., Conant, R.T., Foster, I., Godfray, H.C.J., Herrero, M., Howitt, R.E., Janssen, S., Keating, B.A., Munoz-Carpena, R., Porter, C.H.,
Rosenzweig, C., Wheeler, T.R., 2017. Brief history of agricultural systems modeling. Agric. Syst. 155, 240-254. https://doi.org/10.1016/j.agsy.2016.05.014.

Keady, S.M., Waters, S.M., Hamill, R.M., Dunne, P.G., Keane, M., Richardson, R.I., Kenny, D.A., Moloney, A.P., 2017. Compensatory growth in crossbred Aberdeen Angus and Belgian Blue steers: Effects on the colour, shear force and sensory characteristics of longissimus muscle. Meat Sci. 125, 128-136. https://doi.org/10.1016/j.meatsci. 2016.11.020.

Keane, M.G., Allen, P., 1998. Effects of production system intensity on performance, carcass composition and meat quality of beef cattle. Livest. Prod. Sci. 56, 203-214. https://doi.org/10.1016/S0301-6226(98)00155-9.

Keane, M.G., Drennan, M.J., 1987. Lifetime growth and carcass composition of heifers and steers non-implanted or sequentially implanted with anabolic agents. Anim. Prod. 45, 359-369. https://doi.org/10.1017/S0003356100002853.

Keane, M.G.G., Drennan, M.J.J., Moloney, A.P.P., 2006. Comparison of supplementary concentrate levels with grass silage, separate or total mixed ration feeding, and duration of finishing in beef steers. Livest. Sci. 103, 169-180. https://doi.org/10. 1016/j.livsci.2006.02.008.

Keele, J.W., Williams, C.B., Bennett, G.L., 1992. A computer model to predict the effects of level of nutrition on composition of empty body gain in beef cattle: I. Theory and development. J. Anim. Sci. 70, 841-857.

Kenny, D., Waters, S., McGee, M., 2014. Improving the Feed Efficiency of Beef Cattle. Teagasc Publications, Oak Park, Carlow, Ireland.

Kenny, D.A., Fitzsimons, C., Waters, S.M., McGee, M., 2018. Invited review: improving feed efficiency of beef cattle - the current state of the art and future challenges. Animal 12, 1815-1826. https://doi.org/10.1017/S1751731118000976.

Kilpatrick, D.J., Steen, R.W.J., 1999. A predictive model for beef cattle growth and carcass composition. Agric. Syst. 61, 95-107. https://doi.org/10.1016/S0308-521X(99) 00040-2.

Koknaroglu, H., Loy, D.D., Wilson, D.E., Hoffman, M.P., Lawrence, J.D., 2005. Factors affecting beef cattle performance and profitability. Prof. Anim. Sci. 21, 286-296. https://doi.org/10.15232/S1080-7446(15)31220-1.

Langemeier, M., Schroeder, T., Mintert, J., 1992. Determinants of cattle finishing profitability. South. J. Agric. Econ. 24, 41-47. https://doi.org/10.1017/ S0081305200018367.

Lawrence, P., Kenny, D.A., Earley, B., McGee, M., 2012. Grazed grass herbage intake and performance of beef heifers with predetermined phenotypic residual feed intake classification. Animal 6, 1648-1661. https://doi.org/10.1017/S1751731112000559.

Lesschen, J.P., van den Berg, M., Westhoek, H.J., Witzke, H.P., Oenema, O., 2011. Greenhouse gas emission profiles of European livestock sectors. Anim. Feed Sci. Technol. https://doi.org/10.1016/j.anifeedsci.2011.04.058.

Likert, R., 1932. A technique for the measurement of attitudes. Arch. Psychol. https:// www.doi.org/2731047.

Lopes, R.B., Canozzi, M.E.A., Canellas, L.C., Gonzalez, F.A.L., Corrêa, R.F., Pereira, P.R.R.X., Barcellos, J.O.J., 2018. Bioeconomic simulation of compensatory growth in beef cattle production systems. Livest. Sci. 216, 165-173. https://doi.org/10.1016/j. livsci.2018.08.011.

Lu, D., Miller, S., Sargolzaei, M., Kelly, M., Vander Voort, G., Caldwell, T., Wang, Z., Plastow, G., Moore, S., 2013. Genome-wide association analyses for growth and feed efficiency traits in beef cattle. J. Anim. Sci. 91, 3612-3633. https://doi.org/10.2527/ jas. 2012-5716.

Makulska, J., Kristensen, A.R., 1999. Economic optimization of bull fattening. In: Schiefer, G., R. Helbig, U.R. (Eds.), Perspectives of Modern Information and Communication Systems in Agriculture. Food Production and Environmental Control, Bonn, pp. 443-449.

McGee, M., 2016. Aspects of Feed Efficiency in Beef Production. Teagasc Publications, Oak Park, Carlow, Ireland, pp. 1-9.

McGee, M., 2014. Feed efficiency in beef finishing systems. Teagasc-IGFA Nutr. Conf. June, vol. 2014. WWW Document], URL https://www.teagasc.ie/media/website/ publications/2014/. (Accessed 7.5.18)

Montanholi, Y.R., Haas, L.S., Swanson, K.C., Coomber, B.L., Yamashiro, S., Miller, S.P., 2017. Liver morphometrics and metabolic blood profile across divergent phenotype for feed efficiency in the bovine. Acta Vet. Scand. 59, 24. https://doi.org/10.1186/ s13028-017-0292-1.

Nguyen, T.L.T., Hermansen, J.E., Mogensen, L., 2010. Environmental consequences of different beef production systems in the EU. J. Clean. Prod. 18, 756-766. https://doi. org/10.1016/j.jclepro.2009.12.023.

Nielsen, B.K., Kristensen, A.R., Nielsen, B.K., Kristensen, A.R., 2002. A model for sil multaneous optimization of feeding level and slaughtering policy of organic steers. Conf. Pap. 27-32.

Nielsen, B.K., Kristensen, A.R., Thamsborg, S.M., 2004. Optimal decisions in organic steer production-a model including winter feed level, grazing strategy and slaughtering policy. Livest. Prod. Sci. 88, 239-250. https://doi.org/10.1016/j.livprodsci.2003.11. 010 .

Nix, J., Redman, G., 2016. John Nix Farm Management Pocketbook. Agro Business Consultants.

Nkrumah, J.D., Okine, E.K., Mathison, G.W Schmid, K., Li, C., Basarab, J.A., Price, M.A Wang, Z., Moore, S.S., 2006. Relationships of feedlot feed efficiency, performance, and feeding behavior with metabolic rate, methane production, and energy partitioning in beef cattle. J. Anim. Sci. 84, 145-153.

OECD/FAO, 2017. OECD-FAO Agricultural Outlook 2017-2026. OECD-FAO Agricultural Outlook. OECD Publishinghttps://doi.org/10.1787/agr_outlook-2017-en.

OFX Group Ltd, 2018. Yearly Average Rates. OFX. [WWW Document]. URL https://www. ofx.com/en-gb/forex-news/historical-exchange-rates/yearly-average-rates/. (Accessed 6.4.18).

Oltjen, J.W., Ahmadi, A., 2013. Taurus: a ration formulation program for beef cattle. Nat. Sci. Educ. 42, 145. https://doi.org/10.4195/nse.2011.00003. 
Oltjen, J.W., Bywater, A.C., Baldwin, R.J., Garrett, W.N., 1986. Development of a dynamic model of beef cattle growth and composition. J. Anim. Sci. 62, 86-97.

Paz, H.A., Hales, K.E., Wells, J.E., Kuehn, L.A., Freetly, H.C., Berry, E.D., Flythe, M.D., Spangler, M.L., Fernando, S.C., 2018. Rumen bacterial community structure impacts feed efficiency in beef cattle. J. Anim. Sci. 96, 1045-1058. https://doi.org/10.1093/ jas/skx081.

Peters, G.M., Rowley, H.V., Wiedemann, S., Tucker, R., Short, M.D., Schulz, M., 2010. Red Meat Production in Australia: Life Cycle Assessment and Comparison with Overseas Studies. Environ. Sci. Technol. 44, 1327-1332. https://doi.org/10.1021/es901131e.

Pianosi, F., Beven, K., Freer, J., Hall, J.W., Rougier, J., Stephenson, D.B., Wagener, T., 2016. Sensitivity analysis of environmental models: a systematic review with prac tical workflow. Environ. Model. Softw. 79, 214-232. https://doi.org/10.1016/j. envsoft.2016.02.008.

Pingali, P., 2007. Westernization of Asian diets and the transformation of food systems: implications for research and policy. Food Policy 32, 281-298. https://doi.org/10. 1016/j. foodpol.2006.08.001.

Pitchford, W.S., 2004. Genetic improvement of feed efficiency of beef cattle: what lessons can be learnt from other species? Aust. J. Exp. Agric. 44, 371. https://doi.org/10. 1071/EA02111.

Poore, J., Nemecek, T., 2018. Reducing food's environmental impacts through producers and consumers. Science 360 (80), 987-992. https://doi.org/10.1126/science. aaq0216.

Popkin, B.M., 2006. Technology, transport, globalization and the nutrition transition food policy. Food Policy 31, 554-569. https://doi.org/10.1016/j.foodpol.2006.02.008.

Quality Meat Scotland, 2017. The Scottish Red Meat Industry Profile, 2017th ed.

Quality Meat Scotland, 2013. Better Soil and Grass Management for Scottish Beef and Lamb Producers.

Qureshi, M.E., Harrison, S.R., Wegener, M.K., 1999. Validation of multicriteria analysis models. Agric. Syst. 62, 105-116. https://doi.org/10.1016/S0308-521X(99)00059-1.

Richardson, E.C., Herd, R.M., Archer, J.A., Arthur, P.F., 2004. Metabolic differences in Angus steers divergently selected for residual feed intake. Aust. J. Exp. Agric. 44, 441. https://doi.org/10.1071/EA02219.

Robert Forster, 2015. ABP Changes UK Beef Pricing Grid - Cattle Farmers Face Tougher Penalties. Agriland.iE. [WWW Document]. URL https://www.agriland.ie/farmingnews/abp-changes-uk-beef-pricing-grid-cattle-farmers-face-tougher-penalties/. (Accessed 6.18.18)

Rotz, C.A., Buckmaster, D.R., Comerford, J.W., 2005. A beef herd model for simulating feed intake, animal performance, and manure excretion in farm systems. J. Anim. Sci. 83, 231-242. https://doi.org/10.3168/jds.S0022-0302(03)74032-6.

Ruiz, D.E.M., Pardo Sempere, L., García Martínez, A., Rodríguez Alcaide, J.J., Pamio, J.O., Peña Blanco, F., Domenech García, V., 2000. Technical and allocative efficiency analysis for cattle fattening on Argentina pampas. Agric. Syst. 65, 179-199. https:// doi.org/10.1016/S0308-521X(00)00032-9.

Rykiel, E.J., 1996. Testing ecological models: the meaning of validation. Ecol. Modell. 90, 229-244. https://doi.org/10.1016/0304-3800(95)00152-2.

SAC Consulting, The Farm Management Handbook 2017/18, SAC Consulting, Edinburgh. Sainz, R.D., De la Torre, F., Oltjen, J.W., 1995. Compensatory growth and carcass quality in growth-restricted and refed beef steers. J. Anim. Sci. 73, 2971-2979.

Sargent, R.G., 2010. Proceedings of the 2010 Winter Simulation Conference B. Johansson, S. Jain, J. Montoya-Torres, J. Hugan, and E. Yücesan, Eds. Simulation. https://doi. org/10.1109/wsc. 2010.5679148.

Sauvant, D., Delaby, L., Nozière, P., 2018. INRA Feeding System for Ruminants. Wageningen Academic Publishers, The Netherlands. https://doi.org/10.3920/978
90-8686-292-4.

Scottish Government, 2014. Beef 2020 Report: a Vision for the Beef Industry in Scotland.

Sinclair, A., Shipway, P., Crooks, B., 2013. TN652: Fertiliser Recommendations for Grassland. SRUC.

Snelling, W.M., Allan, M.F., Keele, J.W., Kuehn, L.A., Thallman, R.M., Bennett, G.L., Ferrell, C.L., Jenkins, T.G., Freetly, H.C., Nielsen, M.K., Rolfe, K.M., 2011. Partialgenome evaluation of postweaning feed intake and efficiency of crossbred beef cattle. J. Anim. Sci. 89, 1731-1741. https://doi.org/10.2527/jas.2010-3526.

Steen, R.W.J., Kilpatrick, D.J., 1995. Effects of plane of nutrition and slaughter weight on the carcass composition of serially slaughtered bulls, steers and heifers of three breed crosses. Livest. Prod. Sci. 43, 205-213. https://doi.org/10.1016/0301-6226(95) 00046-N.

Swain, M., Blomqvist, L., McNamara, J., Ripple, W.J., 2018. Reducing the environmental impact of global diets. Sci. Total Environ. 610-611, 1207-1209. https://doi.org/10. 1016/j.scitotenv.2017.08.125.

Takeda, M., Uemoto, Y., Inoue, K., Ogino, A., Nozaki, T., Kurogi, K., Yasumori, T., Satoh, M., 2018. Evaluation of feed efficiency traits for genetic improvement in Japanese black cattle. J. Anim. Sci. 96, 797-805. https://doi.org/10.1093/jas/skx054.

Tess, M.W., Kolstad, B.W., 2000. Simulation of cow-calf production systems in a range environment: II. Model evaluation. J. Anim. Sci. 78.

The Scottish Farmer, 2018. Farming News and Opinions From Across Scotland. [WWW Document]. URL http://www.thescottishfarmer.co.uk/. (Accessed 6.1.18).

The Scottish Government, 2015a. Total Income from Farming: Estimates for Scotland 2012 to 2014.

The Scottish Government, 2015b. Results from the June 2015 Scottish Agricultural Census.

The Scottish Government, 2008. Guidelines for Farmers in Nitrate Vulnerable Zones. [WWW Document]. URL http://www.gov.scot/Publications/2008/12/12134339/6. (Accessed 12.28.17).

Tilman, D., Clark, M., 2014. Global diets link environmental sustainability and human health. Nature 515, 518-522. https://doi.org/10.1038/nature13959.

van Calker, K.J., Berentsen, P.B.M., de Boer, I.M.J., Giesen, G.W.J., Huirne, R.B.M., 2004. An LP-model to analyse economic and ecological sustainability on Dutch dairy farms: model presentation and application for experimental farm "de Marke.". Agric. Syst. 82, 139-160. https://doi.org/10.1016/j.agsy.2004.02.001.

Veysset, P., Bebin, D., Lherm, M., 2005. Adaptation to Agenda 2000 (CAP reform) and optimisation of the farming system of French suckler cattle farms in the Charolais area: a model-based study. Agric. Syst. 83, 179-202. https://doi.org/10.1016/j.agsy. 2004.03.006.

Villalba, D., Casasús, I., Sanz, A., Bernués, A., Estany, J., Revilla, R., 2006. Stochastic simulation of mountain beef cattle systems. Agric. Syst. 89, 414-434. https://doi.org/ 10.1016/j.agsy.2005.10.005.

Vose Software, 2018. Quantitative Risk Analysis Software. Vose Software. [WWW Document]. URL https://www.vosesoftware.com/index.php. (Accessed 6.18.18).

Vosough Ahmadi, B., Shrestha, S., Thomson, S.G.G., Barnes, A.P.P., Stott, A.W.W., 2015 Impacts of greening measures and flat rate regional payments of the Common Agricultural Policy on Scottish beef and sheep farms. J. Agric. Sci. 153, 676-688. https://doi.org/10.1017/S0021859614001221.

Warren, H.E., Scollan, N.D., Enser, M., Hughes, S.I., Richardson, R.I., Wood, J.D., 2008 Effects of breed and a concentrate or grass silage diet on beef quality in cattle of 3 ages. I: animal performance, carcass quality and muscle fatty acid composition. Meat Sci. 78, 256-269. https://doi.org/10.1016/j.meatsci.2007.06.008. 